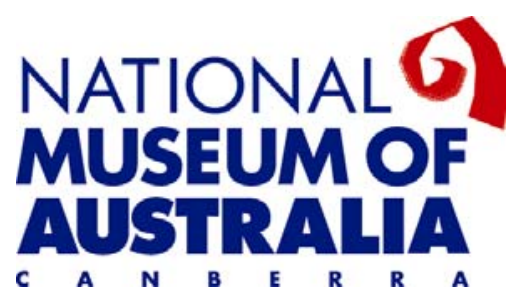

Not Just Ned: A true history of the Irish in Australia An exhibition developed and presented by the National Museum of Australia

\title{
OBJECT BIOGRAPHY
}

\section{'A noble whale ship and commander' - The Catalpa rescue, April 1876}

In 1874, Irishman John Devoy, living in the United States, must have been astonished to receive a letter from a British convict serving a life sentence in Western Australia. The writer James Wilson wrote that his was a 'voice from the tomb ... For is not this a living tomb'. Wilson was one 12 Irish political prisoners, members of an Irish republican organisation called the Fenians, still serving long sentences as British soldiers for 'mutinous conduct'. Altogether 62 'Fenians', convicted of crimes ranging

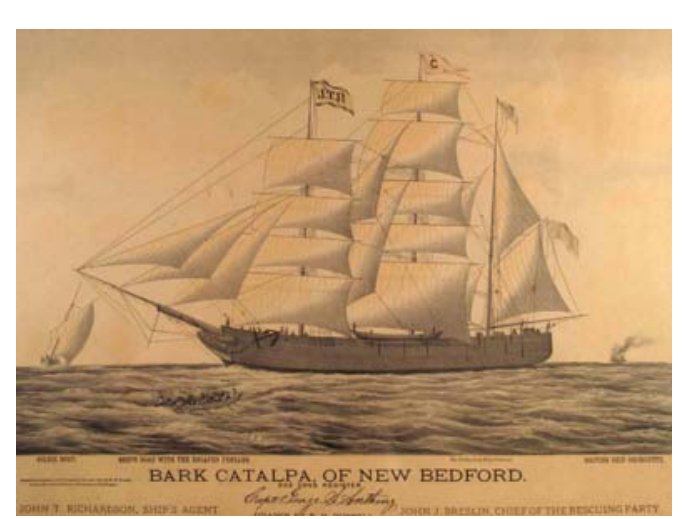

Bark catalpa of New Bedford 1876 by EN Russell, New Bedford Whaling Museum from 'treason-felony' to outright rebellion, had been transported to Western Australia in 1868 on the last Australian convict ship, the Hougemount. By 1874, all had been released except the so-called 'military Fenians', men such as Wilson. They thought the British would leave them to rot in prison to make an example to others for their 'double' treachery to country and uniform.

Devoy responded quickly to this terrible appeal. One of the key Fenian leaders in America, he organised the purchase of an American whaling ship, the Catalpa, in New Bedford, Massachusetts, and for the ship to sail to Western Australia to rescue his Fenian brothers from their British prison in Fremantle. As leader of the expedition, and captain of the Catalpa, Devoy chose George Smith Anthony, an American with no Irish connections. Anthony felt sorry for the Fenians, men he thought were being persecuted for love of country. Two Fenian agents, John Breslin and Thomas Desmond, were sent to Western Australia, to organise the rescue on the ground. 
On 29 March 1876, The Catalpa arrived off the Western Australian coast south of Perth. Contact was made with six Fenian prisoners capable of making the break and on 17 April, Easter Monday and Perth Regatta Day, Breslin and Desmond drove the six prisoners at a furious pace in horse-traps 20 miles south of Fremantle to Rockingham pier where Anthony was waiting for them with one of the Catalpa's whale boats. The escape was soon discovered by which time the whaleboat was on its way out to sea towards the waiting Catalpa. Breslin sent a telegram to the Governor of Western Australia, Irishman William Robinson, which began - 'This is to certify that I have this day released from the clemency of Her Gracious Majesty Queen Victoria, Queen of Great Britain, etc.,etc., six Irishmen condemned to imprisonment for life ... for having been guilty of the atrocious and unpardonable crimes, known to the unenlightened portion of mankind as 'love of country' and 'hatred of tyranny'. But the Fenians were not yet safe and clear. They sighted the Catalpa, but a fierce squall struck breaking the whaleboat's mast and the Catalpa vanished into the growing darkness. The Fenians and their rescuers were obliged to spend a cold night at sea. During that afternoon as well, police cutters from Fremantle and Bunbury were out seeking the escapees and from Perth Governor Robinson had also despatched the steamer Georgette with a contingent of the colony's Pensioner Guard.

On the morning of April 18, the Georgette found the Catalpa, but in Captain Anthony's absence the First Mate refused to allow the colonial police to board as the ship was in international waters outside the colony's three mile limit. After steaming around, the Georgette was forced to go back into Fremantle for coal. The Fenians were finally brought safely on board the whaleboat narrowly avoiding capture by one of the police cutters. On shore the public mood sympathised with the escapees who were seen as 'political' prisoners being punished for an offence against a government not society. The authorities, however, were determined to recapture the Irish rebels. The Georgette was coaled up and, with a small cannon on board, headed out to find the Catalpa.

On the morning of 19 April 1876 there occurred off Fremantle one of the most dramatic events in Australia's colonial maritime history. At first light the Catalpa was sighted by her pursuers who soon drew alongside. On the whaler the Fenian escapees had armed themselves and were determined not to be recaptured. With Breslin hiding behind the gunwale, Captain Anthony faced off the challenges and threats from the Georgette to heave too and prepare to be boarded. When threatened that his masts would be blown in, and under Breslin's prompting, the Yankee skipper pointed to the American flag flying behind the ship: 'That's the American flag; I am on the high seas; my flag protects me; if you fire on this ship you fire on the American flag'. 
the Georgette headed back to Fremantle. The Catalpa sailed to New York where the local Irish community gave the six Fenians a tumultuous welcome.

One of the lasting legacies of the event was a song, sung in the streets and pubs of Western Australia, much to the annoyance of the authorities who sought, unsuccessfully, to ban its singing. This is no surprise as the words were aimed at their failure to properly guard their prisoners:

A noble whale ship and commander,

Called the Catalpa they say,

Came out to Western Australia,

And took six poor Fenians away.

So come all you screw warders and gaolers,

Remember Perth Regatta Day;

Take care of the rest of your Fenians,

Or the Yankees will steal them away.

For the exhibition Not Just Ned: A true history of the Irish in Australia the National Museum of Australia will have on display, for the first time anywhere, the Catalpa's 'JTR' agent's flag, a portrait of Captain Anthony, as well as Anthony's barometer, navigational instruments and the ship's box, in which the captain would have kept his logs. The box carries the words 'Bark Catalpa'. The 'JTR' pennant was flying high on the masthead throughout the rescue. Coming to the NMA for the exhibition's opening is Jim Ryan, Anthony's great, great grandson, who is now the custodian of these, and other, significant reminders of the Catalpa rescue.

Not Just Ned: A true history of the Irish in Australia is on show at the National Museum of Australia, Canberra from 17 March-31 July 2011. Admission charges apply.

For more information about the exhibition visit www.nma.gov.au/exhibitions irish in australia

Curator's note prepared by Richard Reid, Senior Curator, National Museum of Australia 